reproduced ; the characteristic strains of lesser songsters like the chaffinch and willow-wren are faithfully recorded; and the calls of cuckoo and dove-even the non-vocal drumming of the spotted woodpecker -lend pleasing variety. The quality is incomparably superior to that of previous records obtained from captive birds of a few species. These records will certainly give much pleasure and useful instruction : they may also provide valuable opportunities for analytical study of bird music. No doubt more will be made, for different kinds of birds, now that the example has been set. It is clear, too, that there are other subjects to which this interesting innovation of the 'sound book' may in future be applied.

\section{Advances in Radium Therapy Technique}

Teleradium therapy progresses in Great Britain, and more than one big unit is now established, for, apart from those centralized under the control of the Radium Beam Therapy Research, there is a $4 \mathrm{gm}$. unit at Westminster Hospital's Radium Annexe, where physicists and engineers have combined in devising an efficient form of distant electrical control. The radium container is suspended from a rotating beam bolted to a steel girder. This container weighs about $70 \mathrm{lb}$., and the transfer of the radium in it after application to the patients, to a massive safe for purposes of custody, is carried out electrically. There is no actual handling of the radium by any of the staff, the operator being $14 \mathrm{ft}$. from the patient's couch. Another interesting feature of the container used is that it carries a collar of platinum in order to reduce scattering of emergent rays to a minimum. These technical developments in the construction of big units of radium are very welcome, because the ordinary methods of protection for the personnel which are quite efficacious in the case of $\mathrm{X}$-rays are inapplicable with penetrating gamma radiation.

\section{The New Fulham Electrical Power Station}

THE new power station at Fulham on the banks of the Thames was opened formally on September 26. It occupies an area of 15 acres and has a river frontage of 1,300 feet. It is an extension of the existing plant of the Metropolitan Borough of Fulham, but the disparity between its size and the demand required for the borough shows that the new station is an undertaking to serve the Grid. Two sets of 60,000 kilowatts each were installed this year and a third set is now being added. The boiler house is at right angles to the river and the turbine room is parallel to the river. Two white reinforced concrete chimneys three hundred feet high are already built, and when the station is completed there will be four of them. Three colliers have been ordered, each of them capable of carrying 2,300 tons of coal, and the jetty has three travelling cranes each capable of handling 175 tons an hour. The cranes pass the coal to weighing machines, whence it is fed to the furnaces on two belt conveyors which run at 300 feet per minute. Using only two cranes enables a collier to be unloaded in $6 \frac{1}{2}$ hours. When complete and working at approximately half its maximum power, the station will consume roughly 2,000 tons of coal per day.
The final fleet of colliers will consist of six boats capable of sea voyages and of passing under the seventeen bridges up the River Thames to Fulham. The new station has a dignified appearance and in conjunction with the Battersea power station on the opposite bank of the Thames will enable the Central Electricity Board to balance the London load.

There has been considerable opposition to the location of 'super' stations in urban areas, mainly on the ground that their chimneys emit grit and noxious vapours. But the gas washing plants at Fulham are so efficient that this objection has little weight. Each boiler is provided with sulphur extraction plant in the form of two separate units each provided with a separate induced draught fan. The sulphur extraction plant employs grid packing irrigated by a liquor containing suitable alkali so as to maintain intimate contact between the boiler gas and the washing liquor. The liquor system is known as the Howden non-effluent system. The washing medium is constantly recirculated and purged in order to keep the concentration of solid at the best value. The solids extracted are dealt with by a separate and external settlement plant. The amount of liquor recirculated through a complete washer for one boiler unit is 13,000 gallons per minute. Each complete plant is capable of handling 105,000 cubic feet of gas per minute, and the extraction efficiency for sulphur and grit is 98 per cent if the coal have a maximum sulphur content of 1.7 per cent.

\section{The Electricity Grid}

Mr. H. Hobson, in a paper read to the recent World Power Conference at Washington, pointed out some of the advantages that have accrued to Great Britain from the electricity grid. The present trend of the national output of electric supply makes it clear that, before the end of the first ten years of its operation, the system will have effected great economies without cost to the country. In the last three years alone, fuel costs per unit have been reduced 15 per cent and thermal efficienoies have risen more than 12 per cent. In 1925 the reserve generating plant was about 2 million kilowatts, against an aggregate maximum demand of less than 3 million. Last year the reserve showed no increase although the aggregate maximum demand was greater than 6 million. There is one point that is being seriously considered by the Air Raid Precautions Department of the Home Office. There is no doubt that the grid with all its associated superstations will be much more vulnerable to aircraft action in war than the old regime with its independent power stations and few overhead lines. Anti-aircraft forces would doubtless be a help, but permanent protection by camouflage or ctherwise would be very difficult. Unless a super-power station were taken absolutely by surprise, palliative measures could be devised to prevent damage to the stations linked with it.

\section{Estimates of Future U.S. Power Supplies}

Some conclusions from the reports given at the third World Power Conference as to how long 
petroleum, coal, natural gas and water power will last in the United States, have been issued by Science Service, Washington, D.C. There is a possibility of a shortage of domestic petroleum so early as 1940 , and by 1945 the shortage may be serious. There is no cause for alarm in the figures reported, but wasteful methods of drilling and using are deplored. The question of coal conservation is considered immediate and urgent. The life of the coal resources at the recent maximum demand is about 2,000 years. With the probable increased demand of the future, the life may be measured in hundreds of years only. For natural gas the known domestic reserves are seventeen to twenty times the annual consumption. For water power, only a small percentage of the total potential hydro-electric power has yet been developed; but in making estimates, many other factors have to be considered in connexion with navigation, recreation, wild life, soil conservation, etc. One of the reports suggests the possibility of replacing all the 'manufactured gas', usually made from coal, with the by-product gas of petroleum refineries. The second most important gas resource of America is the nearly 200,000 million cubic feet of gas which has been stripped of all the condensable constituents that can be used in motor fuel. In the generation and distribution of electric power, engineers have effected notable economies in fuel consumption and the use of materials. This is a conservation step in the right direction, but many engineers think that more careful engineering is required in the mining of coal to reduce waste. Power is also used for purposes that constitute only a waste of what the engineers have so economically produced.

\section{Enzymologia}

IT is with mixed feelings that we extend a welcome to yet another scientific journal. Enzymologia is edited by Dr. Carl Oppenheimer, assisted by an international group of distinguished collaborators, and bears the imprint of Dr. W. Junk, of The Hague, on its cover as publisher. It is to be an international monthly journal for the publication of researches relating to the enzymes. Two parts appeared, in July and August, containing twenty papers in English, French and German, and it is stated that two further parts are in the press. The subscription price for the volume of about 400 pages in six parts is 15 Dutch florins. We write "mixed feelings" because all of us, including the libraries which are the chief subscribers to the periodical literature nowadays, agree there are already too many journals both to read and to purchase. The advantages to the specialist in having his reading mainly provided for him in one journal are considerable, but against this must be set the inevitable curtailment of his general reading, tending to produce a narrow outlook. Notwithstanding these remarks, it is clear that a welcome awaits a journal devoted to progress in enzyme chemistry, the more especially since this is a field which is due for intense cultivation, leading to marked progress during the next few years. Enzymologia in no way conflicts with the now popular "Ergebnisse der Enzym-Forschung", which is an annual summary. The issue of the new journal from The Hague is one more example, if such indeed were needed, of the progress of biological chemistry in Holland; the first issue begins appropriately with a contribution from a distinguished Dutchman, Prof. A. J. Kluyver of Delft.

\section{Conversazione of the Quekett Microscopical Club}

BY kind permission of the Royal Society, the Quekett Microscopical Club is holding its annual conversazione in the rooms of the Royal Society at Burlington House at 7 p.m. on Tuesday, October 13. Not only will there be a large number of exhibits staged by members of the Club, but also the Committee responsible for the organization of the conversazione has been fortunate in enlisting the symathy and co-operation of other well-known scientific workers and microscopical clubs. The Royal Society is exhibiting original communications from Van Leeuwenhoek and drawings by Hooke. In addition, exhibits have been received from the Natural History Society of Cape Town, from the Microscopical Society of Victoria, Australia, from microscopists in France, the United States and various microscopical societies in Great Britain. A series of cinematographic exhibits on microscopical, pond and other life, also of the development of the bird ovum, will be given at intervals during the evening by Messrs. Kodak, Ltd. Cards of admission can be obtained on application to Mr. W. S. Warton, 35 Doneraile Street, London, S.W.6.

\section{The Osborne Reynolds Ridge}

SINCE the letters on the subject appeared in NATure, the Reynolds line has been seen by readers both on fresh-water and sea-water. Some of those who have seen it, however, missed the note in the News and Views columns of the July 4 issue (p. 20), giving references extending back to a paper by Prof. Osborne Reynolds. Mr. K. G. Denbigh, of Draidland, Norton Road, Norton-on-Tees, Durham, has sent an account of his observations. He saw the line at the fort of Carrawburgh, where a spring rises in a circular pool about five feet deep and eight feet in diameter. It formed a loop, roughly circular and about twelve inches across, surrounding the spot where the water rising from the bottom broke the surface. Apart from this small area where the water was perfectly clear, the pool was, no doubt, covered with a film; he refers to pollen grains and other small vegetable matter floating on it. As Reynolds explains in his paper, the line is only stationary if the rate of spread. ing of the film over the clean surface of the water is balanced by the outward motion of the water. $\mathrm{Mr}$. Denbigh found that the loop was sensitive to wind, contracting to a point when disturbed and expanding again when the wind died down. He also noticed and sketched the distortion of reflections of reeds where they appeared to cross the line. He watched the line for nearly an hour, until a few soap shavings thrown into the water proved to be an overdose for this sensitive phenomenon. 